\title{
Synthesis, characterization, DNA binding and anticancer property of mer-trichlorodimethylsulphoxide- $S-(1,10-$ phenanthroline) ruthenium (III)
}

\author{
P. Hazarika, J. Deka, S. Kamarkar, S.Bhola, R.K.Bhola,O.K Medhi and C. \\ Medhi* \\ Chemistry Department, Gauhati University P.O.Gauhati University
}

\begin{abstract}
The mer-trichloro dimethylsulphoxide-S-(1,10-phenanthroline) ruthenium (III)
([Ru(phen)(DMSO $\left.\mathrm{Cl}_{3}\right]$ ) complex has been synthesized. The structure has been characterized from FT-IR, ${ }^{l} \mathrm{H}$ $N M R$ and UV-Vis spectroscopic data. The geometry of this complex determined by single crystal $X$-ray diffraction study was found to be octahedral. The binding of this complex with Calf Thymus DNA (CT-DNA) has been investigated by spectroscopic, electrochemical and electrophoresis studies. Anticancer activity of this compound studied both in vivo and in vitro against Dalton's lymphoma in mice was found to be significant.
\end{abstract}

Keywords: DNA, Ruthenium complex, Calf thymus, Anticancer activity, Dalton's Lymphoma.

\section{Introduction:}

Metal-based compounds constitute a discrete class of chemotherapeutics widely used as anticancer and antiviral agents. Most established antitumor metal-based drugs are cisplatin and its analogues, such as carboplatin and oxaliplatin. Cisplatin is an anticancer agent being used for the treatment of testicular, ovarian, head, neck and germ cell tumors (Rosenberg B,1985 and Bertino JR et al., 1997). However, the optimal use of this drug is limited due to its dose limiting nephrotoxicity. The new platinum compounds like carboplatin and oxaliplatin are found to possess comparatively very narrow therapeutic index, and also it has limited clinical utility due to drug resistance and side effects(Dabholkar M et al.,1996 and Shimada H et al.,1993). Hence it is necessary to look for more effective and less toxic other metal-based anticancer agents.

Ruthenium complexes have attracted much interest as alternative drug to cisplatin in cancer chemotherapy. Ruthenium complexes have similar ligand exchange kinetics as platinum (II) complexes and exist in different oxidation states under different physiological conditions(Jakupec M A et al., 2005 and Schluga $P$ et al., 2006). Many reviews that illustrate the unique DNA binding modes and antitumor effects have been reported (Kostova I 2006). Ruthenium complexes are presently receiving great attention in the fields of biological, pharmaceutical and medicinal chemistry as anti-tumor agents. Ruthenium compounds show low systematic toxicity and appear to penetrate reasonably well within the tumor cells, binding effectively to DNA and proteins and presenting in some cases selective anti-metastatic properties (Brabec V and Novakova O, 2006) However, it is essential to design superior drugs in terms of effectiveness compared to cisplatin and other metal drugs (Rosenberg B et al.,1965). The 1-10 phenanthroline (phen) ligand has been found in many metalbased anticancer agents (Clarke MJ et al., 1999 Vessieres A et al., 2006, Morris RE et al., 2001, Hong-Ke Liu et al., 2011 and Finlay GJ et al., 2000). There are certain metal complexes with different types of ligands, which are in fact found to be quite effective anticancer agents(Kostova I 2006, Clarke M J 2003 and Bratsos I et al., 2007). Moreover, extensive studies on the biological properties of potential metal-based anticancer agents of phen and DMSO ligands have been found in literatures. There are numerous ruthenium complexes containing phenanthroline ligand and some of these complexes acquire good anticancer activity (Tysoe SA et al., 1993 and Liu J et al., 2008). Again the $\mathrm{Ru}(\mathrm{II})$ and $\mathrm{Ru}(\mathrm{III})$ complexes of dimethyl sulfoxide (DMSO) ligand are known for good anticancer activity (Murali S et al., 2002, Sun S et al., 2009 Yong-guang Y et al., 2011, D. P. Rillema et al.,1982 and Hartinge CG et al., 2008).

The cis- $\left[\mathrm{RuCl}_{2}\left(\mathrm{NH}_{3}\right)_{4}\right] \mathrm{Cl}$, fac- $\left[\mathrm{RuCl}_{3}\left(\mathrm{NH}_{3}\right)_{3}\right]$ and trans-HIm[ $\left.\mathrm{RuCl}_{4}(\mathrm{Im})_{2}\right]$ complexes are some of the anticancer agents effective against primary tumour cells (Thota $\mathrm{S}$ et al., 2012, Stubbs M et al., 1996, Li-Feng Tan et al., 2005, Anghileri L J, et al., 1975, Allardyce CS et al., 2005, Paul H et al., 2012, Wang F et al., 2003 and Nomizo A, et al., 2010). The ligands like isatin, thio semicarbazones, and chloro-fluoro-phenyl are also found in some $\mathrm{Ru}$ (II) complexes and the cytotoxic activity both in vivo and in vitro studies of these complexes are promising (Karki SS et al., 2007). Similarly, NAMI emerges out as anti-metastatic agent, but only small fraction of the compound can reach the tumour target (Galanski M et al., 2003, Sava G et al., 2002 and Arandjelovic SS et al.,2009). Here, the synthesized complex [Ru(phen)(DMSO)Cl $\left.\mathrm{D}_{3}\right]$ ) $\mathrm{Ru}(\mathrm{III})$ complex has been characterized and the DNA binding ability as well as antitumor activity against Dalton's Lymphoma have been examined. 
Materials:

\section{Experimental section:}

Analytical grade $\mathrm{RuCl}_{3} \cdot 3 \mathrm{H}_{2} \mathrm{O}$ was purchased from Sigma, and used without purification. Calf Thymus DNA(CT-DNA), tris-buffer and tetrabutylammonium perchlorate(TBAP) were obtained from Sigma-Aldrich, USA. CT-DNA was dissolved in tris-buffered saline ( $\mathrm{pH} 7.6$,TBS), and dialyzed overnight against the same buffer so that $\mathrm{A}_{260} / \mathrm{A}_{280}$ of the dialyzed solution should be >1.8 (Anghileri L J et al., 1975). The 1,10phenanthroline (phen) and other solvents were used as received.

\section{Synthesis of mer-trichlorodimethylsulphoxide-S-(1,10-phenanthroline) ruthenium (III) complex.}

The compound was prepared by refluxing cis- $\mathrm{Ru}($ phen $) \mathrm{Cl}_{4} \cdot 2 \mathrm{H}_{2} \mathrm{O}$ with dimethylsulphoxide (DMSO) in solvent of ethanol and water mixture for half hour. Cis- $\mathrm{Ru}(\mathrm{phen}) \mathrm{Cl}_{4} \cdot 2 \mathrm{H}_{2} \mathrm{O}$ was synthesised by refluxing $\mathrm{RuCl}_{3} \cdot 3 \mathrm{H}_{2} \mathrm{O}$ with phen according to the procedure given in literature (Krause RA 1977). Then evaporated the solvent by heating in water bath and subsequently purified the compound. The purity of the compound was checked by thin layer chromatography (TLC). The mer-trichlorodimethylsulphoxide-S-(1,10-phenanthroline) ruthenium (III) compound was obtained as a red colored crystal with $80 \%$ yield. IR (KBr) values are 1646 (C=N aromatic), $1090(\mathrm{~S}=\mathrm{O}), 3064$ (C-H, SP ${ }^{2}$ Carbon), 3012, 2926, 2852 (C-H methyl) 1591, 1538, 1413 (C=C aromatic), 450 and 429 (Ru-N and $\mathrm{Ru}-\mathrm{S}) .{ }^{1} \mathrm{H} \mathrm{NMR}\left(\mathrm{CDCl}_{3}-\mathrm{d} 6300 \mathrm{MHz}\right)$ values at 10.18, 8.52 and $8.25 \mathrm{ppm}$ for $\mathrm{N}-\mathrm{H}, \mathrm{C}-\mathrm{H}$ and $\mathrm{C}-\mathrm{H}$ bonds of 1,10 phenanthroline ligand was found. The values at 2.19 and 2.66 ppm for two methyl groups of DMSO, $7.24 \mathrm{ppm}$ for solvent $\mathrm{CDCl}_{3}$ and $1.5 \mathrm{ppm}$ for water impurity in $\mathrm{CDCl}_{3}$ were found. Anal. calculated for C14 H14 N2 : C, 34.78; H, 2.90; N, 5.80. Found: C, 34.75; H, 2.80; N, 5.72.

\section{Crystal structure determination:}

Single crystal X-ray diffraction data was obtained at $100 \mathrm{~K}$ with Brunker smart AXS diffractometer with graphite-monochromatised Mo-K $\alpha$ radiation by $\phi-\omega$ scans. We used full matrix least square on $\mathrm{F}^{2}$. The molecular graphic structure was analyzed by ORTEP plot program. The structure was refined by using SHELXL-97, other materials were prepared by wingx publication routine (Figure 1) (Barton JK and Raphael AL et al.,1984).

Crystal data: Molecular formula $\mathrm{C}_{14} \mathrm{H}_{14} \mathrm{Cl}_{3} \mathrm{~N}_{2} \mathrm{O}_{1} \mathrm{~S}_{1} \mathrm{Ru}_{1}$, formula weight $465.75 \mathrm{gmol}^{-1}, \mathrm{a}=8.8458(8) \AA$, $\mathrm{b}=11.9754(10) \AA, \mathrm{c}=16.7314(14) \AA, \alpha=92.220(4)^{\mathrm{o}}, \quad \beta=104.317^{\circ}(4), \gamma=92.945(4)^{\mathrm{o}}$, cell volume $=1712.7(3)$ $\AA^{3}, \mathrm{Z}=4$, Dcal $=1.806 \mathrm{gcm}^{-3}$, triclinic, space group p-1. Data Collection: Bruker Smart Apex II CCD, Mo-K $\alpha$ radiation $(\lambda=0.71073 \AA)$, graphite monochromator, Crystal size $0.52 \times 0.23 \times 0.14 \mathrm{~mm}^{3}, 296(2) \mathrm{K}, \omega$ and $\Phi$ scan, $3.9^{\circ} \leq 2 \theta \leq 60.18^{\circ},-12 \leq \mathrm{h} \leq 12,-16 \leq \mathrm{k} \leq 16,-23 \leq \mathrm{I} \leq 2335146$ reflection measured, 9885 unique, $\mu(\mathrm{Mo}-\mathrm{K} \alpha)$ $1.51 \mathrm{~mm}^{-1}$, experimental absorption collection with Multi-scan (Sheldrick GM 1996 ).

Structure solution and refinement: The structure was solved by SHELXS97 (Sheldrick GM 1997), and refinement was carried out by full-matrix least square on $\mathrm{F}^{2}$ using the same program SHELXL97. All non-H atoms are refined with anisotropic temperature factors and the hydrogen atoms were positioned from the different synthesis map with isotropic temperature factors of $\operatorname{Uiso}(\mathrm{H})=1.2 \mathrm{Uiso}(\mathrm{C})$ for $\mathrm{CH}$ and $0.114 \mathrm{Uiso}(\mathrm{C})$ for $\mathrm{CH}_{3} .401$ refined parameters, final $R I=0.0347, w R 2=0.0892$ for 8001 reflections with $I>2 \sigma I$, and final $R I=0.0478, w R 2=0.0994$ for all data, with largest peak difference and hole of $0.780 /-0.726 \mathrm{e}^{-3}$ in the vicinity of the $\mathrm{Cl}_{3}$ and $\mathrm{O}_{1}$ atom. The structural data has been deposited to Cambridge Crystallographic Data Center (CCDC 889313).

\section{Spectroscopic studies on DNA binding:}

The spectroscopic, electrochemical and electrophoresis studies of this Ru complex with Calf Thymus DNA (CT-DNA) have been carried out. We observed distinct spectral shift after mixing the complex with CTDNA. It might be due to CT-DNA binding by this complex.

\section{UV-Visible Absorption Titration:}

The UV-visible absorption spectra of $\left[\mathrm{Ru}(\mathrm{phen})(\mathrm{DMSO}) \mathrm{Cl}_{3}\right]$ complex in presence of CT-DNA has been performed (Figure 2). The experiment was performed by maintaining constant concentration of the complex with varying CT-DNA concentrations within the range of $0.59 \times 10^{-5} \mathrm{M}$ to $2.96 \times 10^{-5} \mathrm{M}$. The absorption spectra of the complex are characterized by two distinct intense transitions at $400 \mathrm{~nm}$ and $273 \mathrm{~nm}$, which are the characteristic of metal to ligand charge transfer(Ru (dpi)-(Lpi*) transition). With the of the concentrations CTDNA from $0.59 \times 10^{-5} \mathrm{M}$ to $2.96 \times 10^{-5} \mathrm{M}$, absorbance intensity of both the two peaks decreased without shifting the wavelengths(Tables 1 and Figure 2). These spectral characteristics might be due to the binding of CT-DNA with the complex. To estimate quantitatively the binding strength of $\left[\mathrm{Ru}(\mathrm{phen})(\mathrm{DMSO}) \mathrm{Cl}_{3}\right]$, the intrinsic binding constants $\left(\mathrm{K}_{\mathrm{b}}\right)$ was calculated from the following equation (Shahabadi $\mathrm{N}$ et al., 2011 and Rathinasamy S et al.,2006). 


$$
\frac{\varepsilon_{\mathrm{b}}-\varepsilon_{\mathrm{f}}}{\varepsilon_{\mathrm{a}}-\varepsilon_{\mathrm{f}}}=\frac{1}{[\mathrm{DNA}] \mathrm{k}_{\mathrm{b}}}+1
$$

where $\varepsilon_{\mathrm{a}}, \varepsilon_{\mathrm{f}}$ and $\varepsilon_{\mathrm{b}}$ are the extinction coefficients of observed solution, free complex and the solution of the complex with maximum CT-DNA concentration. The value of $\mathrm{K}_{\mathrm{b}}$ was obtained from the slope of the plot

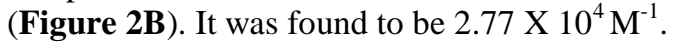

\section{Fluorescence Emission Titration:}

To further investigate the interaction of the complex with CT-DNA fluorescence titration experiment was performed. The emission spectra of the complex at excitation wavelength of $280 \mathrm{~nm}$, and in presence of varying amounts of CT-DNA are shown in Figure 3. On increasing the concentrations of CT-DNA from 0.59 $\mathrm{X} 10^{-5} \mathrm{M}$ to $4.1 \mathrm{X} 10^{-5} \mathrm{M}$, a new peak appeared at $445 \mathrm{~nm}$ in addition to the other peak at $324 \mathrm{~nm}$. The intensities of both these peaks have been increased with the increase of CT-DNA (Table 2 and Figure 3). Intercalation by phen ligand of the complex within DNA base pair upon DNA binding might enhance the luminescence of the complex, which is similar to the nature of DNA binding of other previously reported complexes $\left(\mathrm{K}_{\mathrm{B}}=2.77 \mathrm{X} 10^{4}\right.$ $\mathrm{M}^{-1}$ ) ( Rathinasamy S et al.,2006). The value is typical for intercalation by hydrophobic phen ligand.

\section{Electrochemistry:}

Cyclic voltammetric study for $\left[\mathrm{Ru}(\mathrm{phen})(\mathrm{DMSO}) \mathrm{Cl}_{3}\right]$ complex was carried out in DMSO solution $(0.005 \mathrm{M})$ containing $0.1 \mathrm{M}$ TBAP as supporting electrolyte using $\mathrm{Ag} / \mathrm{Ag}^{+}$as reference electrode, and a glassy carbon electrode was used as working electrode. Inert environment was maintained by passing $\mathrm{N}_{2}$ gas through the solution to remove oxygen. The cyclic voltamogram shows distinct oxidation and reduction peaks of a reversible electron transfer couple at scan rate $100 \mathrm{mVs}^{-1}$. The shift of redox potential $\left(\mathrm{E}_{1 / 2}\right)$ from $222 \mathrm{mV}$ to $256 \mathrm{mV}$ on addition of CT-DNA was observed (Figure 4).

\section{Electrophoresis experiment:}

The binding of trichlorodimethylsulphoxide-S-(1,10-phenanthroline) ruthenium (III) complex with CTDNA was further supported by electrophoresis experiment. The solution of CT-DNA was prepared in tris-HCl buffer at $\mathrm{pH}$ 7.6. The binding of complex with CT-DNA was monitored by preparing solutions of the complex having three different concentrations, $6 \mathrm{mM}, 3 \mathrm{mM}$ and $2 \mathrm{mM}$ with CT-DNA, which was incubated for 24 hours at $37^{\circ} \mathrm{C}$ before running Gel Electrophoresis. The three solutions were placed at three different lanes, 1,2 and 3 in the gel along with free CT-DNA $(5 \mathrm{mM})$, which was kept at lane C. The composition of base pairs in the CTDNA used in this experiment was 42 mole for GC, 58 mole for AT in 100 mole. The samples were run from -ve to +ve potential for 3 hours at different voltages (half an hour at $50 \mathrm{~V}, 1$ hour at $60 \mathrm{~V}$, half an hour at $70 \mathrm{~V}$ and 1 hour at $80 \mathrm{~V}$ ) on a $1 \%$ agarose gel prepared in tris-borate EDTA. After photographed the gel under UV light, it appears that lane $\mathrm{C}$ moves faster than lane 1, 2 and 3 and the brightness decreases from lane $\mathrm{C}$ lane 1, 2 and 3 (Figure 5).

Biological studies of trichlorodimethylsulphoxide-S-(1,10-phenanthroline) ruthenium (III) complex: Effect of different concentrations of trichloro dimethylsulphoxide- $S$-(1,10-phenanthroline) ruthenium (III) complex on mice bearing Dalton's lymphoma:

$\mathrm{C}_{3} \mathrm{H} / \mathrm{He}$ strain of mice both male and female, 8-10 weeks old and weighing 20-22g was used in all sets of experiments. Animals were kept in polypropylene cages and were fed on a commercial diet (Goldmohar, Lipton, India) and tap water ad libitum. Mice were kept under standard condition (especially pathogen free, temperature ranging from $22-23^{\circ} \mathrm{C}$ and relative humidity $65-70 \%$. Transplantable ascites Dalton's lymphoma was obtained from Chittaranjan National Cancer Research Centre, Kolkata, India and maintained in the laboratory by regular serial transplantations by injecting $2 \times 10^{7}$ cells/mice in PBS after a regular interval of 10 days. Ruthenium compound, trichlorodimethylesulphoxide- $S$-(1,10-phenanthroline) ruthenium (III) was prepared in the laboratory as mentioned. All other chemicals were purchased from Hi-media, Mumbai, India and were of analytical grade.

Control and experimental animals were selected randomly and divided into groups of 10 mice each according to randomized block design. Each animal was transplanted with $3 \times 10^{6}$ cells/mice. After 4 days of post-tumor transplantation, the experimental mice were treated with single i.p. injection of different concentrations of trichloro dimethylsulphoxide-S-(1,10-phenanthroline) ruthenium (III) dissolved in Phosphate buffered saline (PBS) (pH 7.4). Control animals were injected with equal amount of PBS. In each group \% Survival, increase in the mean survival time of tumor bearing mice and tumor free survivors were observed.

Effect of trichlorodimethylsulphoxide-S-(1,10-phenanthroline) ruthenium (III) complex on the survival of Dalton's lymphoma cells in vivo: 
Dalton's lymphoma cells were isolated from the peritoneal cavity of tumor bearing mice (control and treated with different concentrations of this Ru complex). 2-3 ml of sterile phosphate buffered saline (PBS) was injected into the peritoneal cavity and the fluid containing the tumor cells was withdrawn, and collected in sterile petridishes for incubation at $37^{\circ} \mathrm{C}$ for 2 hours. The cells of macrophage lineage adhered to the bottom of petridishes to form a confluent monolayer. The non-adherent population of lymphoma cells was gently aspirated out and washed repeatedly with PBS. The viability was tested by tryphan blue exclusion test.

\section{Effect of trichlorodimethylsulphoxide-S-(1,10-phenanthroline) ruthenium (III) on the survival of Dalton's lymphoma cells in vitro:}

For cytotoxicity assay in vitro, Dalton's lymphoma cells were plated at high density $\left(8 \times 10^{7}\right.$ cells/dish) at time 0 in DMEM containing fetal calf serum, $10 \mathrm{mM} \mathrm{NaHCO}_{3}, 0.3 \%$ glutamine and different concentrations of Ru complex for a fixed treatment duration of 1 hour. Control dishes were treated with equal amount of PBS used as a solvent for trichlorodimethyl sulphoxide -S- (1,10-phenanthroline) ruthenium(III). At the end of drug treatment, cells were harvested and washed with PBS, suspended again in ADM with DFCS and incubated for 72 hours at $37^{0} \mathrm{C}$. After incubation, cells were trypsinized and viable cells were counted by tryphan blue exclusion test.

\section{Results and Discussion:}

The geometry around the ruthenium atom of $\left[\mathrm{Ru}(\mathrm{phen})(\mathrm{DMSO}) \mathrm{Cl}_{3}\right]$ is found to be octahedral with a phen ligand occupying two coordination sites while the other coordination sites are occupied by one DMSO and three chlorine atoms. The compound was prepared by refluxing the $\mathrm{RuCl}_{3} \cdot 3 \mathrm{H}_{2} \mathrm{O}$ and phen in solvent mixture of ethanol and water, and subsequent addition of DMSO. Initially, the two $\mathrm{Cl}$ atoms might be replaced by phen ligand, and then DMSO molecule reacts with $\mathrm{Ru}(\mathrm{phen}) \mathrm{Cl}_{4} \cdot 2 \mathrm{H}_{2} \mathrm{O}$ to replace the inner $\mathrm{Cl}$ atom to give $\left[\mathrm{Ru}(\right.$ phen $\left.)(\mathrm{DMSO}) \mathrm{Cl}_{3}\right]$. The crystalline compound so obtained was analyzed by XRD studies and the ORTEP structure is shown in Figure 1. The molecular structure of $\left[\mathrm{Ru}(\mathrm{phen})(\mathrm{DMSO}) \mathrm{Cl}_{3}\right]$ complex shows a slightly distorted octahedral arrangement around the ruthenium atom. The metal atom is bonded to one bi-dentate 1,10phenanthroline ligand, three chlorine atoms and a dimethylsulphoxide ligand through the sulphur atom. The bond distances between $\mathrm{Ru}$ metal and other coordinating ligands reasonable with those of other already synthesized complexes, like $\left.\mathrm{RuCl}(\mathrm{DMSO})(1,10-\mathrm{phen})_{2}\right]\left[\mathrm{BPh}_{4}\right], \quad$ cis- $\mathrm{Ru}(\mathrm{DMSO})_{4} \mathrm{Cl}_{2}$ and $\left[\left(\eta^{6}-\right.\right.$ $\left.\mathrm{C}_{6} \mathrm{Me}_{6}\right) \mathrm{Ru}\left\{\left(\mathrm{C}_{5} \mathrm{H}_{4} \mathrm{~N}\right)_{2} \mathrm{C}=\mathrm{NMe}\right\} \mathrm{Cl}_{3} \mathrm{PF}_{6}$ (Karki SS et al., 2007).The Ru-N bond trans to $\mathrm{S}$ is found longer than the other Ru-N bond. The variation of Ru-N bond lengths may be due to the influence of $\pi$ electrons of $\mathrm{Cl}$ and $\mathrm{S}$ atoms to the Ru-N bonding (Karki SS et al., 2007). Both the solid as well as the solution state absorption spectra of the complex show two distinct peaks at the $\lambda_{\max }$ at $273 \mathrm{~nm}$ and $400 \mathrm{~nm}$. The infrared spectra of the complex are observed at wavelengths, $1086 \mathrm{~cm}^{-1}, 449 \mathrm{~cm}^{-1}$ and $414 \mathrm{~cm}^{-1}$ respectively. The potential bonds corresponding to these observed spectral peaks are $-\mathrm{S}=\mathrm{O},-\mathrm{Ru}-\mathrm{N}$ and $\mathrm{Ru}-\mathrm{S}$. The ${ }^{1} \mathrm{H}$ NMR study cannot clearly detect the peaks of corresponding ligands.

Further studies were carried out to understand the binding of this complex with CT-DNA. Absorbance intensities of the peaks at $400 \mathrm{~nm}$ and $273 \mathrm{~nm}$ have decreased with the increase of CT-DNA concentrations from $0.59 \times 10^{-5} \mathrm{M}$ to $2.96 \times 10^{-5} \mathrm{M}$ (Table 1 and Figure 2). The observed spectral characteristics suggest strong interactions between $\left[\mathrm{Ru}\left(\right.\right.$ phen)(DMSO)Cl $\left.\mathrm{Cl}_{3}\right]$ complex with CT-DNA. The intrinsic binding constant, $\mathrm{K}_{\mathrm{b}}$ is found to be $2.77 \times 10^{4} \mathrm{M}^{-1}$. The fluorescence spectra of the complex is found different from the spectra taken after mixing with CT DNA(Figure 3). In addition to the original apex at $324 \mathrm{~nm}$ of the complex, a new peak was observed at $445 \mathrm{~nm}$, which becomes more intense on increasing the concentrations of CT-DNA from $0.59 \times 10^{-5}$ $\mathrm{M}$ to $4.1 \mathrm{X} 10^{-5} \mathrm{M}$ (Table 2 and Figure 3). Such observable spectral shifts and change in intensity indicate the binding of $\left[\mathrm{Ru}(\mathrm{phen})(\mathrm{DMSO}) \mathrm{Cl}_{3}\right]$ complex with CT-DNA. The spectral peak of CT-DNA taken at $\mathrm{pH} 7.4$ is $260 \mathrm{~nm}$, and the $\pi-\pi *$ transition for aromatic ligand(phen) is found at $266 \mathrm{~nm}$. A broad band $>400 \mathrm{~nm}$ corresponds to metal to ligand charge transfer $\left(\mathrm{E}_{2 \mathrm{~g}}-\pi^{*}\right)$ (Lever ABP 1984). Such typical spectral characteristics suggest intercalation of phen ligand with CT-DNA(Li L et al., 2012) base pairs.

The redox potentials obtained from Osteryoung Square Wave Voltammetry (OSWV) of the complex and after mixing with CT-DNA were found at $224 \mathrm{mV}$ and $256 \mathrm{mV}$ respectively (Figure 4). The binding of the complex with CT-DNA can be inferred from the positive shift in the redox potential $(34 \mathrm{mV})$ after mixing with CT-DNA. Such positive shift of potential might be due to intercalation of hydrophobic phen ligand with DNA base pairs (Medhi OK et al., 1997). The positive shift in the potential might also increase the stability of $\mathrm{Ru}^{\mathrm{I}}$ after binding to DNA. The observed $\mathrm{E}_{1 / 2}$ of this complex is very close to the reported value of NAMI $\left[\mathrm{Na}^{+}\left(\mathrm{RuCl}_{4}(\mathrm{dmso})(\mathrm{Ima})\right]\right.$ which is $+235 \mathrm{mv}$ (Alessio E et al.,1993). Moreover, we performed electrophoresis experiments to understand the binding of $\left[\mathrm{Ru}(\mathrm{phen})(\mathrm{DMSO}) \mathrm{Cl}_{3}\right]$ complex with CT-DNA. Lane $\mathrm{C}$ moves slightly faster from $-v e$ to $+v e$ side in the gel electrophoresis than lanes, 1, 2 and 3 . The electrophoretic mobilities and brightness of the bands decrease significantly as the concentrations of the complex increases from lane 3 to 1 . Hence, the binding of this complex with CT-DNA has been clearly shown (Figure 5). 
Electrophoresis of CT-DNA $(5 \mathrm{mM})$ revealed a more intense band but when a higher concentrations of CTDNA $(6 \mathrm{mM})$ was mixed with same amount of Ru complex a very weak band was observed (Figure 5). This suggests the formation of DNA adduct with Ru complex. Further, as the concentration of CT-DNA was increased from 2-6 mM and mixed with same amount of Ru complex, the sharpness of DNA band was found to decrease indicating direct correlation between the amounts of DNA and adduct formation.

As we know that the metallic drugs, cisplatin is an important class of chemotherapeutic agent widely used in cancer chemotherapy, but its clinical use is limited due to nephrotoxicity (Kim YK et al., 1995 and Wolfgang GHI, et al., 1994). Among the transition metal compounds, Ruthenium appears to be a likely candidate in near future even though its chemistry differs from that of platinum. The most significant differences are its octahedral geometry and greater propensity to undergo redox reactions. The hypoxic environment of many tumors may favor the reduction of ruthenium (III) compounds to ruthenium (II) species (Pegg D G et al., 1994 and Clarke MJ et al.,1988). The hydrophobicity of phenanthroline ligand is responsible for DNA binding ability and for possible anticancer activity of this complex (Chen T et al., 2012).

In the present studies a newly synthesized ruthenium compound trichlorodimethylsulphoxide- $S$ - $(1,10-$ phenanthroline) ruthenium(III) was tested against murine's Dalton's lymphoma. Percentage survival of mice bearing tumor after treatment with this compound is shown in Figure 6. A direct correlation was observed between the dose of compound administered and increase in the \% survival of tumor bearing mice. All the control animals without any treatment failed to survive beyond 10 days post tumor transplantation. When the tumor bearing mice were treated with $20 \mathrm{mg} / \mathrm{kg}$ of compound, $100 \%$ of animals survived till day 18 post tumor transplant and the maximum survival period was found to be 28 days. When the dose of ruthenium compound was increased to 30 and $40 \mathrm{mg} / \mathrm{kg}$, the maximum survival time increased to 30-32 days. When the concentration was further increased to $50 \mathrm{mg} / \mathrm{kg}$ the maximum survival period increased to 45 days (Figure 6). The viability of tumor cells was found to depend on the concentrations of ruthenium compound injected in mice. Increasing concentrations of Ruthenium compound had adverse effect on viability of tumor cells. Almost $90 \%$ of viability was observed with $10-20 \mathrm{mg} / \mathrm{kg}$ of compound. However, $30-40 \mathrm{mg} / \mathrm{kg}$ dose has shown $70-80 \%$ viable cells. The $\mathrm{LC}_{50}$ was found to be $50 \mathrm{mg} / \mathrm{kg}$ (Figure 7).

Present study has also shown the effects of Ruthenium compound at the cellular level through a study of its lethal activity in an in vitro system. Results obtained in the present study with Dalton's lymphoma cells are expressions of cell killing assay and not the growth inhibition assay. It was found that cytotoxicity of ruthenium compound depends upon its concentration in the culture media. Survival of Dalton's lymphoma cells treated in vitro with different concentrations of ruthenium complex for a fixed time duration of $1 \mathrm{~h}$ is shown in Figure 8. There exists an inverse linear correlation between the concentration of ruthenium in the medium and $\%$ survival of lymphoma cells. $\mathrm{IC}_{50}$ of ruthenium was found to be $40 \mu \mathrm{g} / \mathrm{ml}$ (Figure 8).

Most of the investigations reporting ruthenium compounds as anti-tumor agents have been carried out as in vitro studies and only a few are in vivo studies. Ruthenium- DMSO complexes have been reported to increase the life span of tumor bearing mice in vivo (Pieper, T and Keppler, BK 1998). These compounds are also effective against several murine models including a cisplatin resistant P 388 leukemia cell line. While a number of Ruthenium compounds have been tested, the prototype compound RAPTA-C has been reported to be most effective anti-cancer compound of this series and has been used extensively against a number of murine cell lines. Chatterjee $\mathrm{S}$ et al studied the effect of RAPTA-C induced apoptosis in EAC cells isolated from peritoneal cavity of tumor bearing mice and found that the apoptosis was dose dependent (Chatterjee S et al., 2008). In the present studies, the effect of compound has also been found to be dose dependent.

In a similar study, flow cytometry analysis of RAPTA-C induced cell cycle phase distribution of nuclear DNA has shown increased content of haploid DNA in RAPTA-C treated cells (Chatterjee S et al., 2008). However, the DNA in S-phases decreased from 6.3 to $3.6 \%$ suggesting that tumor suppressor gene $\mathrm{P}^{53}$ is central to the induction of cell cycle arrest and apoptosis in response to DNA damage of cellular stage in human cells. Earlier it has been reported that ruthenium (III) compounds having significant cytotoxic properties are able to bind firmly to DNA and modify its structural conformation (Brabec V et al.,1995). So the anticancer activity of the present compound may be related to its DNA binding ability.

\section{Conclusion:}

The synthesis of ruthenium complex, its CT-DNA binding and biological studies have been performed. The structure analyzed by single crystal XRD study shows six-coordinated octahedral geometry. The crystal structure is a representative complex, $\left[\mathrm{Ru}(\mathrm{phen})(\mathrm{DMSO}) \mathrm{Cl}_{3}\right]$, and the structural features are in accord with already reported ruthenium complexes. The CT-DNA binding of this complex is evidenced by various experimental techniques. On the basis of spectroscopic shift, the intrinsic binding constant $\left(\mathrm{K}_{\mathrm{b}}\right)$ is found to be $2.77 \mathrm{X} 10^{4} \mathrm{M}^{-1}$. Based on the observed distinct shift of electrochemical $\mathrm{E}_{1 / 2}$ and electrophoresis band shifts, the complex is expected to bind with CT-DNA. The hydrophobicity of the phen ligand may be responsible for DNA binding and possibly related to the anticancer activity of ruthenium complex. 
This compound acquires good antitumor property against Dalton's lymphoma both in vivo and in vitro. The compound exhibited dose dependent increase in the survival time of tumor bearing mice, however, no tumor free survivor was observed. From the biological studies in vivo, the highest dose of this complex is 50 $\mathrm{mg} / \mathrm{kg}$. Electrophoretic analysis of CT-DNA with the complex suggests the formation of DNA adduct, which might be responsible for the antitumor activity of this compound.

\section{References:}

[1]. Rosenberg B, (1985) Fundamental studies with cisplatin. Cancer, 55: 2303-2316

[2]. Pil P, Lippard S. J. Cisplatin and related drugs. Bertino JR, (1997). Encyclopedia of cancer. Academic Press, Inc. San Diego, 1: 392-410.

[3]. Dabholkar M, and Reed E. (eds. Pinedo, H. M., Longo, D. L., Chabner, B. A.) (1996), Elsevier Science Publishers, Netherlands, 88110 .

[4]. Shimada H, Sugimachi N, Funakoshi T and Kojima S, (1993) Prevention of renal toxicity of cis-diamminedichloroplatinum by dithiocarbamates in rats. Toxicol. Lett., 66:193-198.

[5]. Jakupec M A, Reisner E, Eichinger A, Pongratz M, Arion, V B, Galanski M, Hartinger C, Keppler B K, (2005) Redox-Active Redox-Active Antineoplastic Ruthenium Complexes with Indazole: Correlation of in Vitro Potency and Reduction Potential. J Med. Chem., 48: 2831-2837.

[6]. Schluga P, Hartinger G, Egger A, Reisner E, Galanski M, Jakupee MA and Keppler BK, (2006) Redox behavior of tumorinhibiting ruthenium (III) complexes and effects of physiological reductants on their binding to GMP. Dalton Trans, $1796-1802$.

[7]. Kostova I, (2006) Ruthenium complexes as anticancer agents Curr. Med. Chem., 13:1085-107.

[8]. Clarke M J, (2003) Ruthenium Metallopharmaceuticals. Coord. Chem. Rev., 236: 207-231.

[9]. Bratsos I, Jedner S, Gianferrara T, Alessio E, (2007) Ruthenium anticancer compounds. Challenges and Expectations Chimia, 61: 692-697.

[10]. Rosenberg B, Camp LV, Krigas T,(1965) Inhibition of Cell Division in Escherichia coli by Electrolysis Products from a Platinum Electrode Nature. 205: 698 - 699.

[11]. Clarke MJ, Zhu F, Frasca DR, (1999) Non-Platinum Chemotherapeutic Metallopharmaceuticals.Chem Rev, 99: 2511-2533.

[12]. Vessieres A, Top S, Beck W, Hillard E, Jaouen G, (2006) Metal complex SERMs (selective oestrogen receptor modulators). The influence of different metal units on breast cancer cell antiproliferative effects. Dalton Trans 529: 529-541.

[13]. Morris RE, Aird R E, Mudroch P S, Chen H, Cummins J, Hughes ND, Parsons S, Parkin A, Boyd G, Jodrell DI, Sadler PJ, (2001) Inhibition of Cancer Cell Growth by Ruthenium(II) Arene Complexes. J Med. Chem.,44: 3616-3621.

[14]. Hong-Ke Liu, Sadler PJ, (2011) Metal Complexes as DNA Intercalators. Acc. Chem. Res., 44: 349-359.

[15]. Finlay GJ, Baguley BC, (2000) Effects of protein binding on the in vitro activity of antitumour acridine derivatives and related anticancer drugs. Cancer Chemother Pharmacol.45: 417-22.

[16]. Thota S, Imran M, Udugula M, Karki S S, Kanjarla N, Yerra R, Balzarini J and Clercq E D, (2012) Synthesis, spectroscopic characterization antineoplastic, in vitro-cytotoxic, and antibacterial activities of mononuclear ruthenium(II) complexes. J Coord Chem, 65: 823-839.

[17]. Clarke MJ, and Stubbs M,(1996) Interactions of Metallopharmaceuticals with DNA Metal Ions in Biological Systems, 32: 727-780.

[18]. Li-Feng Tan, Hui Chao, Yun-Jun Liu, Hong Li, Bin Sun, Liang-Nian Ji, (2005) DNA-binding and photocleavage studies of $\left[\mathrm{Ru}(\text { phen)2(NMIP) }]^{2+}\right.$. Inorganica Chimica Acta, 358: 2191-2198.

[19]. Anghileri L J, Krebsforsch Z, Onkol K,( 1975) The in vivo inhibition of tumor growth by ruthenium red: its relationship with the metabolism of calcium in the tumor. Cancer Res. Clin Oncol, 83: 213

[20]. Allardyce CS, Dorcier A, Scolaro C, Dyson PJ, (2005) Development of organometallic (organo-transition metal) pharmaceuticals. Appl. Organomet. Chem, 19: 1-10.

[21]. Paul H, Mukherjee T, Drew MGB and Chattopadhyay P, (2012) Synthesis, characterization, crystal structure, and DNA-binding of ruthenium(II) complexes of heterocyclic nitrogen ligands resulting from a benzimidazole-based quinazoline derivative. $\mathrm{J}$ Coord Chem, 65: 1289-1302.

[22]. Wang F, Chen H, Parsons S, Oswald IDH, Davidson JE, Sadler PJ., (2003) Kinetics of Aquation and Anation of Ruthenium(ii) Arene Anticancer Complexes, Acidity and X-ray Structures of Aqua Adducts . Chem Eur J, 9: 5810-5820.

[23]. Elisângel de Paula Silveira-Lacerda, Cesar Augusto Sam Tiago Vilanova-Costa, Pereira FC, Hamaguchi A, Pavanin LA ,Goular LR, Homsi-Brandenburgo MI, Martins SA, Santos W B and Nomizo A, (2010) The Ruthenium Complex cis-(Dichloro) Tetraammineruthenium(III) Chloride Presents Immune Stimulatory Activity on Human Peripheral Blood Mononuclear Cells. Biol Trace Elem Res 133: 270-283

[24]. Karki SS, Thota S, Darj S Y, Balzarinib J and Clercqb E D Bioorg, (2007) Synthesis, anticancer, and cytotoxic activities of some mononuclear Ru(II) compounds. Med Chem., 15: 6632-6641

[25]. Tysoe SA, Morgan R J, Baker D, (1993) Spectroscopic Investigation of Differential Binding Modes of Delta and Lambda$[\mathrm{Ru}(\mathrm{bpy}) 2 \mathrm{ppz}]^{2+}$ with Calf Thymus DNA. J Phys Chem, 97: 1707-1711.

[26]. Liu J, Zheng W, Shi S, Tan C, Chen J, Zheng K, Ji L, (2008) Synthesis, antitumor activity and structure-activity relationships of a series of Ru(II) complexes. J Inorg Biochem, 102: 193-202.

[27]. Murali S, Sastri CV, Maiya BG, (2002) New mixed ligand complexes of ruthenium(II) that incorporate a modified phenanthroline ligand: Synthesis, spectral characterization and DNA binding. Proc. Indian Acad. Sci. (Chem. Sci.), 114: $403-415$.

[28]. Sun S, Yang Y, Liu F, Fan J, Peng X,. Kehr J, Sun L, (2009) Intra- and intermolecular interaction ECL study of novel ruthenium tris-bipyridyl complexes with different amine reductants Dalton Trans, 38: 7969-7974.

[29]. Yong-guang Y, Du L, Yu X, Yan-hui Z, Xue-yun Z , Jie L, (2011) Development of NAMI-A-loaded PLGA-mPEG Nanoparticles: Physicochemical Characterization, in vitro Drug Release and in vivo Antitumor Efficacy. Chem. Res., Chinese Universities, 27: 345-349.

[30]. D. P. Rillema, K. B. Mack, (1982) The Low lying Excited State in Ligand-Acceptor Complexes of Ruthenium(II) Mononuclear and Binuclear Species. Inorg. Chem., 21: 3849-3854.

[31]. Hartinge CG, Jakupec MA., Seifried S Z, Groess1 M, Egger A, Berger W, Zorbas H, Dyson, PJ, Keppler BK, (2008) KP1019 a New Redox-Active Anticancer Agent-Preclinic Development and Results of a Clinical Phase I Study in Tumor Patients. Chemistry \& Biodiversity (Review), 5: 2140-2155.

[32]. Galanski M, Arion VB, Jakupec MA, Keppler BK, (2003) Recent Developments in the Field of Tumor-Inhibiting Metal Complexes. Curr Pharm Des, 9: 2078-2089. 
[33]. Sava G, Bergamo A, Zorzet S, Gava B, Casarsa C, Cocchietto M, Furlani A, Scarcia V, Serli B, Iengo E, Alessio E, Mestroni G, (2002) Influence of chemical stability on the activity of the antimetastasis ruthenium compound NAMI-A. Eur J Cancer, 38: 427435 .

[34]. Arandjelovic SS, Bjelogrlic KS, Malesevic NN, Tesic LjZ, Radulovic SS, (2009) Antitumor activity of Ru(III) complexes carrying beta-diketonato ligands in vitro and in vivo. J Boun, 14: 271-279.

[35]. Krause RA, (1977) Synthesis of mixed complexes of ruthenium(II) with 2,2'-dipyridyl Inorganica Chimica Acta, 22 : $209-213$.

[36]. Barton JK, Raphael AL, (1984) Photoactivated Stereospecific Cleavage of Double-Helical DNA by Cobalt(II1) Complexes. J Am. Chem. Soc., 106: 2466-2468.

[37]. (a). Sheldrick GM (1996), SADABS University of Göttengen, Germany, (b) Sheldrick GM (1997) A program for automatic solution of crystal structure, University of Göttengen, Germany, c) Sheldrick GM (1997) A program for crystal structure refinement, University of Göttengen, Germany.

[38]. Shahabadi N, Mohammadi S, Alizadeh R, (2011) DNA Interaction Studies of a New Platinum(II) Complex Containing Different Aromatic Dinitrogen Ligands. Bioinorganic Chemistry and Application. 2011:1-8.

[39]. [39] Rathinasamy S, Karki SS, ,Bhattacharya S, Manikandan L, Prabakaran S G, Gupta M, Mazumder U K, (2006) Synthesis and anticancer activity of certain mononuclear Ru(II) complexes. J Enzyme Inhibition and Medicinal Chemistry. 21: 501-507.

[40]. Lever ABP, (1984) Inorganic Electronic Spectroscopy, $2^{\text {nd }}$ Edition Elsevier Newyork.

[41]. Li L, Cao W, Zheng W, Fan C and Chen T, (2012) Dalton Trans., 41:12766-12772.

[42]. Das D K, Bhattaray C and Medhi OK,(1997) Electrochemical behaviour of (protoporphyrinato IX) iron(III) encapsulated in aqueous surfactant micelles.Dalton Trans., 4713-4718.

[43]. Alessio E, Balducci G, Lutman A, Mestroni G, Calligaris M and Attia WM, (1993) Synthesis and characterization of two new classes of ruthenium(III)-sulfoxide complexes with nitrogen donor ligands, Inorg. Chim. Acta, 203: 205-217.

[44]. Kim YK, Byun H S, Kim Y H, Woo JS and Lee SH (1995) Effect of cisplatin on renal function in rabbits: mechanism of reduced glucose reabsorption. Toxicol. Appl. Pharmacol., 130: 19-26.

[45]. Wolfgang GH I, Dominick MA, Walsh KM, Hoeschele J D and Pegg D G (1994). Comparative Nephrotoxicity of a Novel Platinum Compound, Cisplatin and Carboplatin in Male Wistar Rats. Fundamental Appl. Toxicol, 22: 73-79.

[46]. Clarke MJ, (1988) Ruthenium in Cancer Chemotherapy. Platinum Metals Rev, 32: 198-199.

[47]. Brabec V, Novakova O, (2006) DNA binding mode of ruthenium complexes and relationship to tumor cell toxicity. Drug Resistance Updates, 9:111-122.

[48]. Pieper, T and Keppler, BK (1998) Tumor-inhibiting ruthenium complexes formulation and analytical characterization. Analusis, 26: $84-90$

[49]. Chatterjee S, Subhadip K, Bhattacharyya A, Hartinger G C and Dyson PJ, (2008) The ruthenium(II)-arene compound RAPTA-C induces apoptosis in EAC cells through mitochondrial and p53-JNK pathways. J Biol. Inorg. Chem., 13: 1149-1155.

[50]. Novakova O, Kasparkova O, Vrano O, Vanviet PM, Reedijk J and Brabec V. (1995) Correlation between Cytotoxicity and DNA Binding of Polypyridyl Ruthenium Complexes Olga. Biochemistry, 34: 12369-12378.

\section{Acknowledgements:}

The authors thank the Department of Science and Technology (DST), New Delhi for financial support and SAIF, Gauhati University for collection Single crystal X-ray intensity data.

Table 1. The wavelengths and absorbances of the complex with and without mixing CT-DNA at different concentrations.

\begin{tabular}{|c|c|c|c|c|c|}
\hline & \multirow[t]{2}{*}{ Samples } & \multicolumn{2}{|c|}{ Wavelengths (nm) } & \multicolumn{2}{|c|}{ Absorbances } \\
\hline & & $\lambda \max (1)$ & $\lambda \max (2)$ & 1 & 2 \\
\hline & DNA & 260 & & 0.061 & \\
\hline $\mathrm{b}$ & Complex & 273 & 400 & 2.034 & 0.367 \\
\hline $\mathrm{c}$ & Complex $+0.59 \times 10^{-5} \mathrm{M}$ DNA & 273 & 400 & 1.977 & 0.333 \\
\hline $\mathrm{d}$ & Complex $+1.10 \times 10^{-5} \mathrm{M}$ DNA & 273 & 400 & 1.908 & 0.327 \\
\hline $\mathrm{e}$ & Complex $+1.78 \times 10^{-5} \mathrm{M}$ DNA & 273 & 400 & 1.884 & 0.322 \\
\hline $\mathrm{f}$ & Complex $+2.37 \times 10^{-5} \mathrm{M}$ DNA & 273 & 400 & 1.869 & 0.319 \\
\hline $\mathrm{g}$ & Complex $+2.96 \times 10^{-5} \mathrm{M}$ DNA & 273 & 400 & 1.844 & 0.315 \\
\hline
\end{tabular}

Table 2. The emission peaks and fluorescence intensities of the complex with and without mixing CT-DNA at different concentrations.

\begin{tabular}{llcc}
\hline & Samples & Apex $(\mathrm{nm})$ & Intensities $( \pm 1)$ \\
\hline $\mathrm{a}$ & DNA & 563 & 33.80 \\
$\mathrm{~b}$ & Complex & 324 & 76.47 \\
$\mathrm{c}$ & Complex $+0.59 \times 10^{-5} \mathrm{M}$ DNA & 324 & 118.40 \\
& & 445 & 33.69 \\
$\mathrm{~d}$ & Complex $+1.78 \times 10^{-5} \mathrm{M}$ DNA & 324 & 124.90 \\
& & 445 & 37.66 \\
$\mathrm{e}$ & Complex $+2.37 \times 10^{-5} \mathrm{M}$ DNA & 324 & 137.90 \\
$\mathrm{f}$ & & 445 & 46.12 \\
$\mathrm{~g}$ & Complex $+3.5 \times 10^{-5} \mathrm{M}$ DNA & 324 & 143.30 \\
& & 445 & 51.71 \\
& Complex $+4.1 \times 10^{-5} \mathrm{M}$ DNA & 324 & 163.70 \\
\hline
\end{tabular}




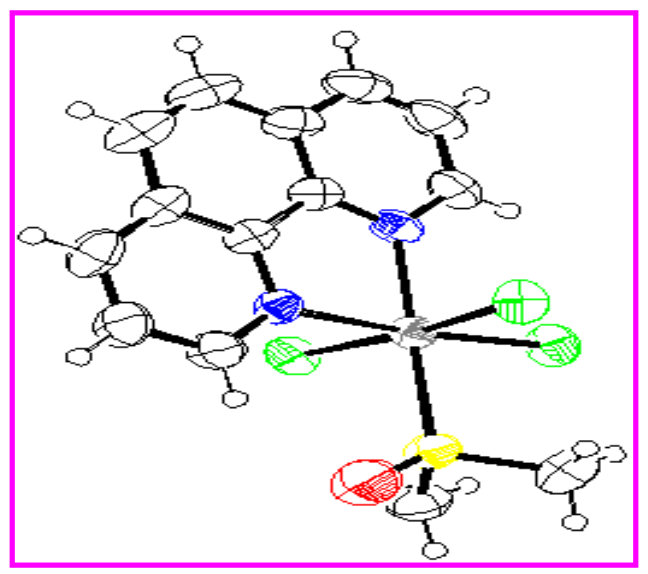

Figure1 ORTEP molecular structure of the $\mathrm{Ru}\left(\right.$ phen)(DMSO)Cl $\mathrm{C}_{3}$ complex. Selected distances/A and bond angles ${ }^{\circ}$

Ru1-N1=2.082(2), Ru1-N2=2.088(2), Ru1-S1=2.320(4), Ru1-Cl1=2.336(2), Ru1-Cl2=2.347(1), Ru1$\mathrm{Cl}=2.346(1), \quad \mathrm{S} 1-\mathrm{O} 1=1.393(4), \quad \mathrm{S} 1-\mathrm{C} 13=1.784(4), \quad \mathrm{S} 1-\mathrm{C} 14=1.770(4), \quad \mathrm{N} 1-\mathrm{Ru} 1-\mathrm{N} 2=79.22(10), \quad \mathrm{Cl} 1-\mathrm{Ru} 1-$ $\mathrm{N} 2=84.94(7), \mathrm{Cl} 2-\mathrm{Ru} 1-\mathrm{N} 2=92.23(7), \mathrm{Cl} 3-\mathrm{Ru} 1-\mathrm{N} 2=95.71(8), \mathrm{Cl} 1-\mathrm{Ru} 1-\mathrm{N} 1=87.48(7), \mathrm{Cl} 2-\mathrm{Ru} 1-\mathrm{N} 1=87.31(7)$, Cl3-Ru1-N1=174.89(4), Cl1-Ru1-Cl2=174.45(3)，Cl3-Ru1-Cl1=92.79(3)，Cl3-Ru1-Cl2=92.24(3)，S1-Ru1$\mathrm{N} 1=97.92(6), \mathrm{S} 1-\mathrm{Ru} 1-\mathrm{Cl} 1=91.31(3), \mathrm{S} 1-\mathrm{Ru} 1-\mathrm{Cl} 2=91.26(3), \mathrm{S} 1-\mathrm{Ru} 1 \mathrm{Cl} 3=87.38(3), \mathrm{Ru} 1-\mathrm{S} 1-\mathrm{O} 1=119.40(1), \mathrm{O} 1-$ $\mathrm{S} 1-\mathrm{C} 13=102.50(3), \mathrm{O} 1-\mathrm{S} 1-\mathrm{C} 14=111.60(3), \mathrm{C} 13-\mathrm{S} 1-\mathrm{C} 14=99.27(4)$.

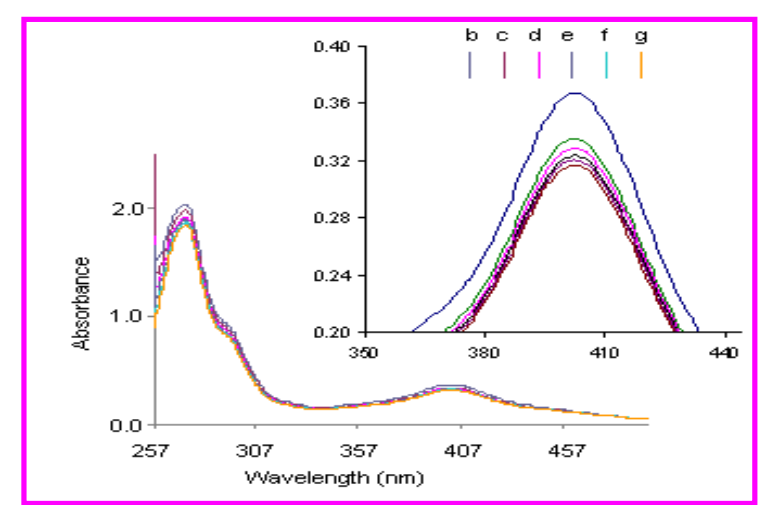

(A)

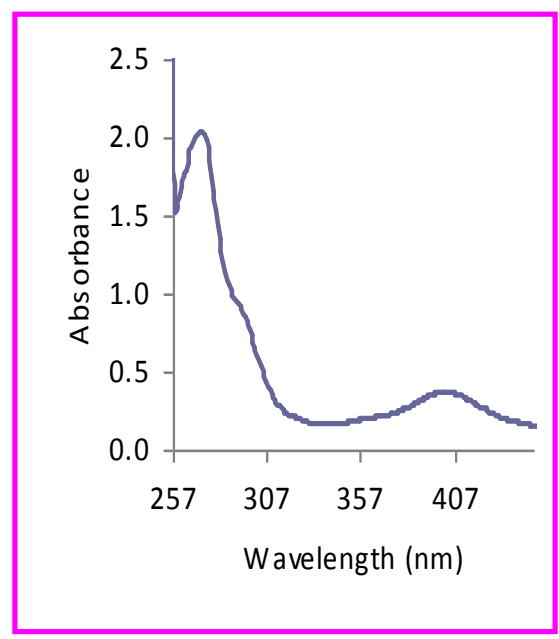

(C)

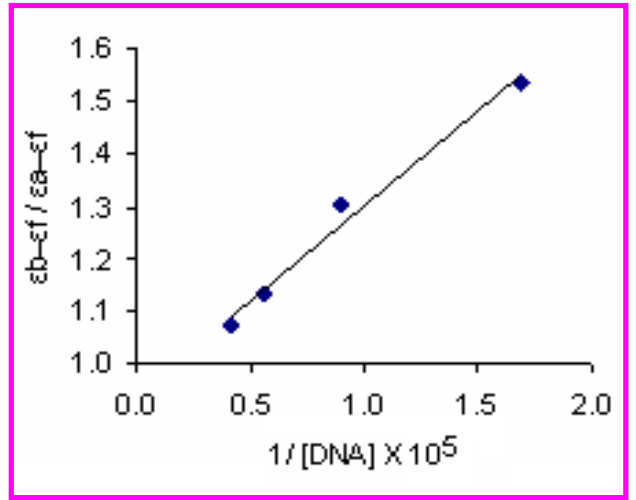

(B)

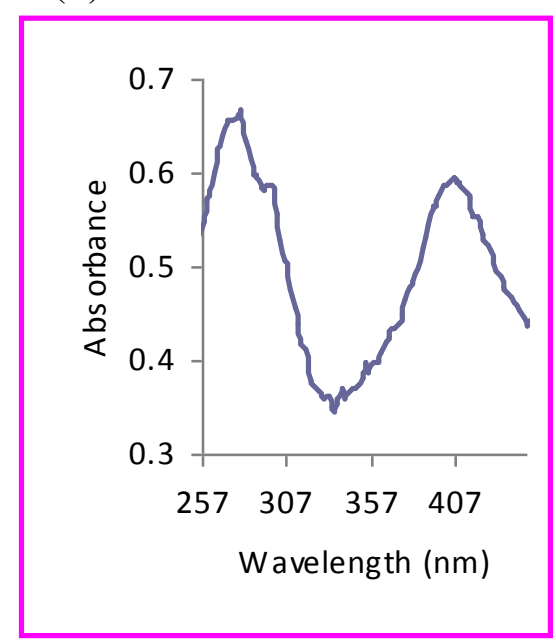

(D)

Figure 2. (A) UV-visible spectra of the $5 \mathrm{mM}$ complex with and without mixing CT-DNA at different concentrations and (A) plot of $\varepsilon_{\mathrm{b}}-\varepsilon_{\mathrm{f}} / \varepsilon_{\mathrm{a}}-\varepsilon_{\mathrm{f}}$ against reciprocal concentration of CT-DNA (1/[DNA]).(C) and (D) are the UV-visible spectra of the complex in DMSO solvent and solid state. The maximum absorption peaks 
$\left(\lambda_{\max }\right)$ for the both state are obtained around at $273 \mathrm{~nm}$ and $400 \mathrm{~nm}$ which may indicates the complex has same structure in the solution as well as solid state.

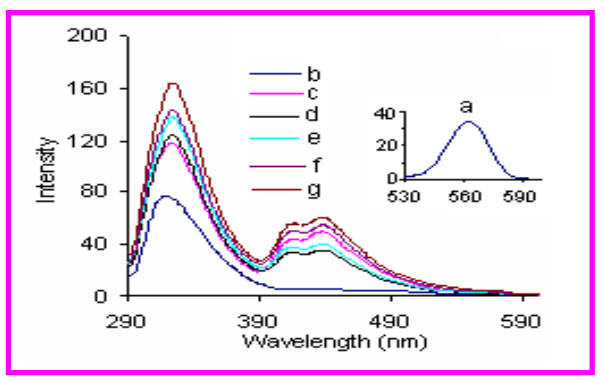

Figure 3. Fluorescence intensity of the $5 \mathrm{mM}$ complex with and without mixing CT-DNA at different concentrations, along with free CT-DNA.

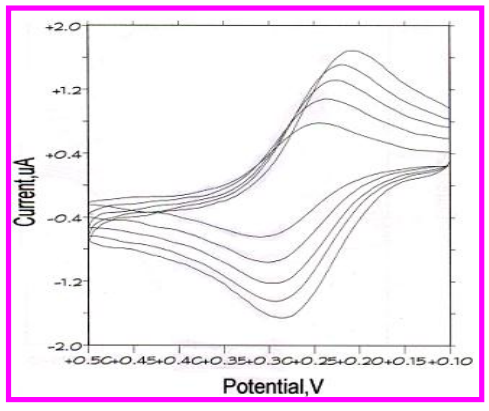

(A)

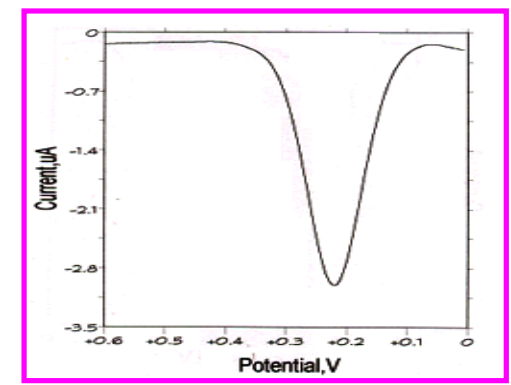

(C)

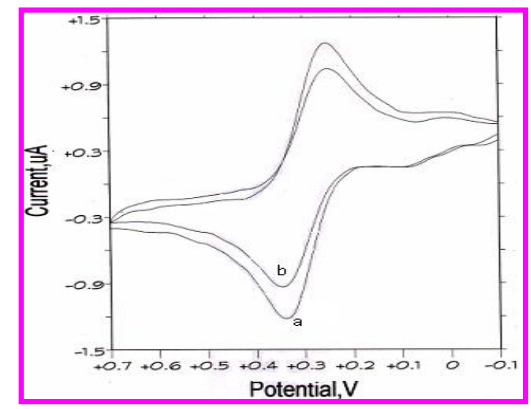

(B)

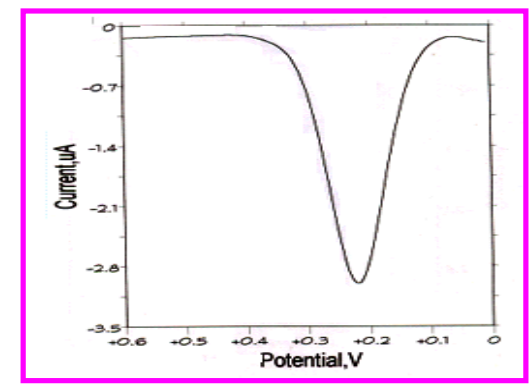

(D)

Figure 4. (A) Cyclic voltammogram of $5 \mathrm{mM}$ complex at different scan rate $(50 \mathrm{mV} / \mathrm{S}$ to $250 \mathrm{mV} / \mathrm{S})$, (B) Cyclic voltammogram of $5 \mathrm{mM}$ the complex (a) and after mixing with $5 \mathrm{mM}$ CT-DNA (b), (C) and (D) are the square wave voltammogram for the $5 \mathrm{mM}$ complex $\left(\mathrm{E}_{1 / 2}=222 \mathrm{mV}\right)$ and the complex in presence of $5 \mathrm{mM}$ CTDNA $\left(E_{1 / 2}=256 \mathrm{mV}\right)$, respectively. The redox potential shows $34 \mathrm{mV}$ positive shift on addition of CT-DNA.

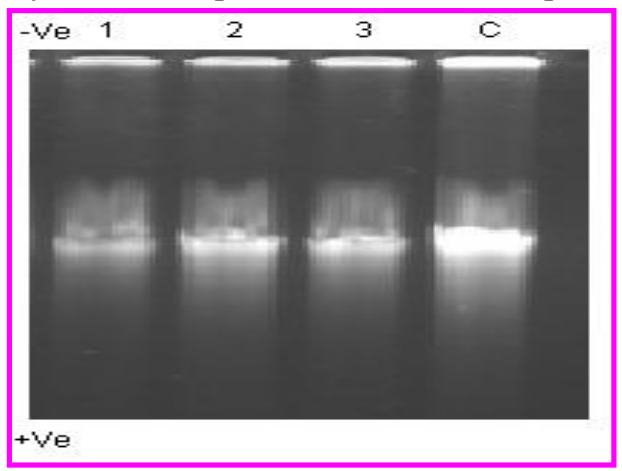

Figure 5. Gel electrophoresis of trichlorodimethylsulphoxide-S-(1,10-phenanthroline) ruthenium (III) complex with CT-DNA $(5 \mathrm{mM})$ studied in gel electrophoresis in tris- $\mathrm{HCl}$ buffer at $\mathrm{pH} 7.6$ (concentration taken are 2 $\mathrm{mM}, 3 \mathrm{mM}, 6 \mathrm{mM}$ as indicated lane $3,2,1)$. 


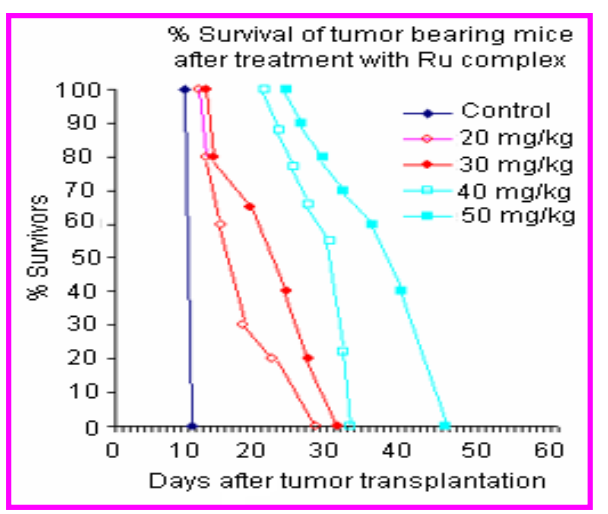

Figure 6. Effect of this Ru complex on mice bearing Dalton's lymphoma. No tumor bearing mice became tumor free after treatment $50 \mathrm{mg} / \mathrm{kg}$ of the complex. Rest of the animals also $(\mathrm{p}<0.05)$ increase in their life span compared to control (compound is dissolved in PBS pH 7.4).

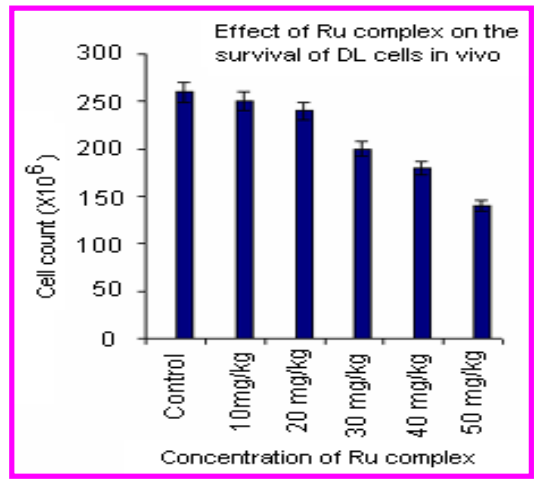

Figure 7. Effect of the complex on the survival of Dalton's lymphoma cells in vivo. The results are an average of five $(n=5)$ independent experiments in triplicate and represented as mean \pm SE. $p<0.05$ vs control.

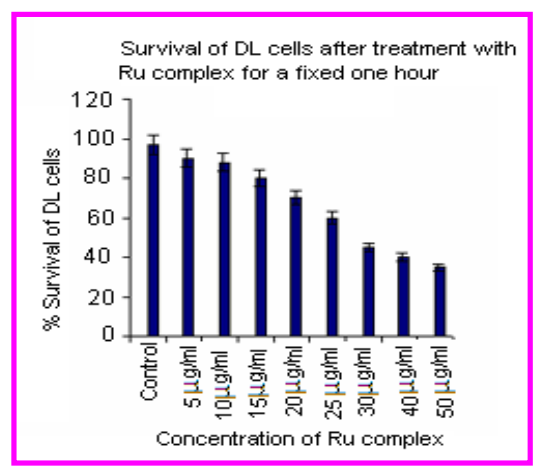

Figure 8. The results are an average of five $(\mathrm{n}=5)$ independent experiments in triplicate and represented as mean \pm SE. $p<0.05$ vs control. 